TADEUSZ STRYJAKIEWICZ

Uniwersytet im. Adama Mickiewicza w Poznaniu

\title{
Przemiany w geografii przemysłu
}

\author{
Życie bez świętowania jest jak dtuga droga bez zajazdów,
} w których podróżny mógtby się pokrzepić i odpoczać.

Demokryt

\section{WSTĘP}

Kolejny tom Prac Komisji Geografii Przemysłu PTG wydany w Instytucie Geografii Uniwersytetu Pedagogicznego im. Komisji Edukacji Narodowej (dawnej Wyższej Szkoły Pedagogicznej, później Akademii Pedagogicznej) w Krakowie w związku z Jubileuszem 80-lecia urodzin Profesora dra hab. Stanisława Misztala - wieloletniego przewodniczącego, a dziś Honorowego Przewodniczącego Komisji Geografii Przemysłu PTG, stanowi dobrą okazję do refleksji na temat przemian, jakie dokonały się w geografii przemysłu, a także do postawienia pytania, w jakim zakresie przemiany te znajdowały odzwierciedlenie w problematyce kolejnych tomów prac Komisji oraz organizowanego od 25 lat cyklu krakowskich konferencji ${ }^{1}$, tak ważnych i zasłużonych dla rozwoju polskiej geografii przemysłu. Nic więc dziwnego, że jako motto niniejszego artykułu wybrano cytat z Demokryta, wyrażający afirmację radości świętowania, w tym przypadku aż dwóch jubileuszy.

Artykuł ten ma zatem charakter okolicznościowy, próbujący godzić perspektywę naukową (syntetyzującą stan i dynamikę wiedzy w dziedzinie geografii przemysłu) z perspektywą jubileuszowego świętowania. Zawiera on również wiele elementów związanych ze wspomnieniami osobistymi. Należę bowiem do tych geografów ekonomicznych, którzy mieli okazję i przyjemność uczestniczenia w wielu krakowskich konferencjach, w tym w tej pierwszej przed 25 laty, zatytułowanej „Geografia przemysłu w akademickim kształceniu nauczycieli”, która odbyła się w dniach 9-10 grudnia 1985 r. Według określenia jej organizatora, Profesora dra hab. Zbigniewa Zioło, byłem wówczas ,przedstawicielem młodszego pokolenia, podejmującego trud rozwijania geografii przemysłu" (Zioło 1987, s. 7). Z kolei jednym z najaktywniejszych dyskutantów był Profesor Misztal, obecny Jubilat. Tak więc mam 25-letnią perspektywę czasową, która - jak sądzę - pozwala mi próbować odpowiedzieć na pytanie, jaką drogę przeszła nasza dyscyplina naukowa (i my wraz z nią) w ciagu minionego ćwierćwiecza.

\footnotetext{
${ }^{1}$ Pełny wykaz konferencji w załączniku.
} 
W artykule podejmuje się dyskusję na temat kilku kwestii, które odzwierciedlają przemiany w geografii przemysłu na przełomie XX i XXI wieku. Dotyczą one m.in.:

a) definiowania zakresu przedmiotowego dyscypliny i podstawowego obiektu badań;

b) trendów metodologicznych i kierunków badań;

c) nowego spojrzenia na problem lokalizacji działalności gospodarczej;

d) miejsca przemysłu w zachodzących współcześnie procesach przestrzennych (tercjaryzacji, dezindustrializacji, transformacji, globalizacji i integracji gospodarki).

W odniesieniu do każdej z tych kwestii starano się odpowiedzieć na pytanie, czy i w jakim stopniu były i są one przedmiotem debat naukowych w Polsce, w tym w ramach konferencji organizowanych w Krakowie przez Instytut Geografii Uniwersytetu Pedagogicznego i Komisję Geografii Przemysłu Polskiego Towarzystwa Geograficznego (a obecnie także przez Sekcję Gospodarki Przestrzennej Komisji Nauk Ekonomicznych PAN w Krakowie).

W drugiej części artykułu podjęto próbę oceny aktualnego stanu polskiej geografii przemysłu.

\section{SYNTETYCZNA CHARAKTERYSTYKA PRZEMIAN W GEOGRAFII PRZEMYSŁU}

Analiza współczesnych przemian w geografii przemysłu jest stosunkowo trudna. Wynika to z kilku przyczyn. Jedną z nich są rosnące trudności w definiowaniu zakresu przedmiotowego dyscypliny. Przemysł jest tym sektorem gospodarki, w którym - m.in. pod wpływem postępu technologicznego (a zwłaszcza nowych technologii informacyjno-komunikacyjnych) - zacierają się granice między znaczną częścią działalności przemysłowej i usługowej. Problematyka dawnej geografii przemysłu „wtapia się” w badania z zakresu geografii ekonomicznej (ujmowanej całościowo, tzn. bez podziału „branżowego”). Jest to tendencja zgodna $\mathrm{z}$ trendem światowym. W aspekcie instytucjonalnym odzwierciedla ją zmiana nazw komisji Międzynarodowej Unii Geograficznej związanych z geografią przemysłu (ryc. 1).

Komisja Geografii Przemysłu

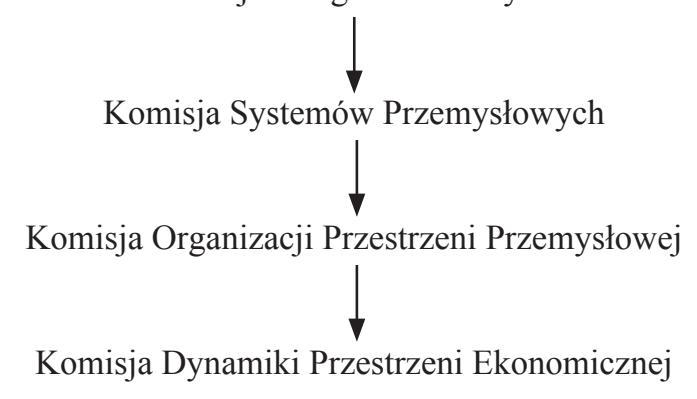

Ryc. 1. Zmiany nazw komisji związanych z geografią przemysłu działających w strukturze Międzynarodowej Unii Geograficznej 
Zwiększają się również trudności w określaniu podstawowego obiektu badań (ryc. 2): kiedyś był to zakład przemysłowy, później przedsiębiorstwo, system przemysłowy, łańcuch produkcji (łańcuch wartości dodanej), obecnie mówi się o globalnych sieciach gospodarczych i w konsekwencji o nowych formach organizacji przestrzennej przemysłu (np. całkowitej zmianie uległ sens pojęcia „okręg przemysłowy”).

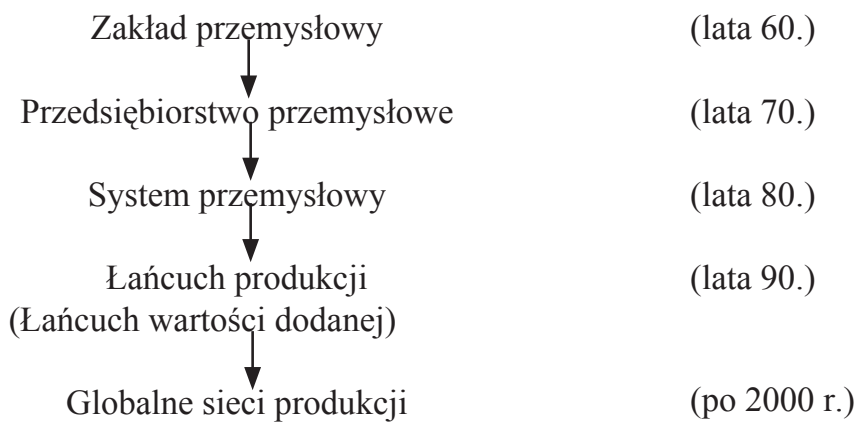

Ryc. 2. Zmiana obiektu badań w geografii przemysłu

Charakteryzując podczas pierwszej krakowskiej konferencji 25 lat temu główne kierunki i problemy badawcze geografii przemysłu, B. Kortus wyróżnił trzy podejścia metodologiczne (uznając je za szczególnie pożądane): neopozytywistyczne (związane z nurtem ilościowym), behawioralne oraz systemowe (Kortus 1987, s. 18-19). Współcześnie najczęściej mówi się o podejściach:

- ewolucyjnym, związanym z koncepcją zależności od ścieżki (path dependence);

- relacyjnym, związanym z koncepcją sieci przemysłowych (industrial networks);

- instytucjonalnym, eksponującym rolę instytucji (formalnych i nieformalnych) w kształtowaniu struktury i organizacji przestrzennej przemysłu oraz decyzjach lokalizacyjnych ${ }^{2}$.

R. Hayter (2004) identyfikuje trzy „filary konceptualne”, na których opiera się obecna geografia ekonomiczna (w tym geografia przemysłu): zakorzenienie (embeddedness), ewolucję i zróżnicowanie. „Fundamentem” badań są społeczne uwarunkowania procesów gospodarczych (ryc. 3).

Punktem wyjścia analizy zmian kierunków badań geografii przemysłu w Polsce jest referat autora niniejszego artykułu wygłoszony podczas pierwszej krakowskiej konferencji, opublikowany w 1987 r. (Stryjakiewicz 1987, fot. 1 i 2³). Zostały w nim wówczas wyróżnione następujące kierunki badawcze:

1. Geneza i rozwój ośrodków, okręgów, regionów przemysłowych oraz gałęzi i branż przemysłu (badania geograficzno-historyczne).

2. Struktura gałęziowa i przestrzenna oraz regionalizacja przemysłu.

\footnotetext{
${ }^{2} \mathrm{~W}$ polskiej literaturze geograficzno-ekonomicznej podejścia te i/lub związane z nimi koncepcje teoretyczne charakteryzują m.in. B. Domański (2004), K. Gwosdz (2004), T. Stryjakiewicz (2001, 2005, 2007) oraz K. Stachowiak (2008).

${ }^{3}$ Zdjęcia te nie tylko przywołują w pamięci pierwszą publikację pokonferencyjną, ale pozwalają też dostrzec zmianę technologii poligraficznej, jaka dokonała się w ciągu minionych 25 lat.
} 
3. Procesy uprzemysłowienia i zjawiska im towarzyszące (m.in. społeczne skutki industrializacji).

4. Związki przemysłu ze środowiskiem geograficznym.

5. Czynniki lokalizacji przemysłu.

6. Przestrzenne powiązania produkcyjne i organizacyjne przemysłu.

7. Ocena efektywności lokalizacji zakładów przemysłowych.

8. Zagadnienia ogólne, teoretyczne i metodologiczne.

Obecnie niektóre z nich zostały zarzucone (np. ocena efektywności lokalizacji zakładów przemysłowych), inne zmieniły swój charakter w związku ze zmianą roli przemysłu we współczesnej gospodarce (np. zamiast analizy procesu uprzemysłowienia bada się raczej procesy dezindustrializacji, reindustrializacji lub restrukturyzacji oraz ich geograficzne konsekwencje), jeszcze inne prowadzone są na podstawie odmiennych założeń teoretyczno-metodologicznych. Dotyczy to m.in. delimitacji i typologii okręgów przemysłowych, które wyznacza się na podstawie usieciowienia, tj. układu relacji, a nie - jak dawniej - na podstawie mierników wielkościowych działalności przemysłowej i kryterium zwartości przestrzennej. Z kolei badania związków przemysłu ze środowiskiem geograficznym prowadzone są najczęściej w powiązaniu z koncepcją zrównoważonego rozwoju.

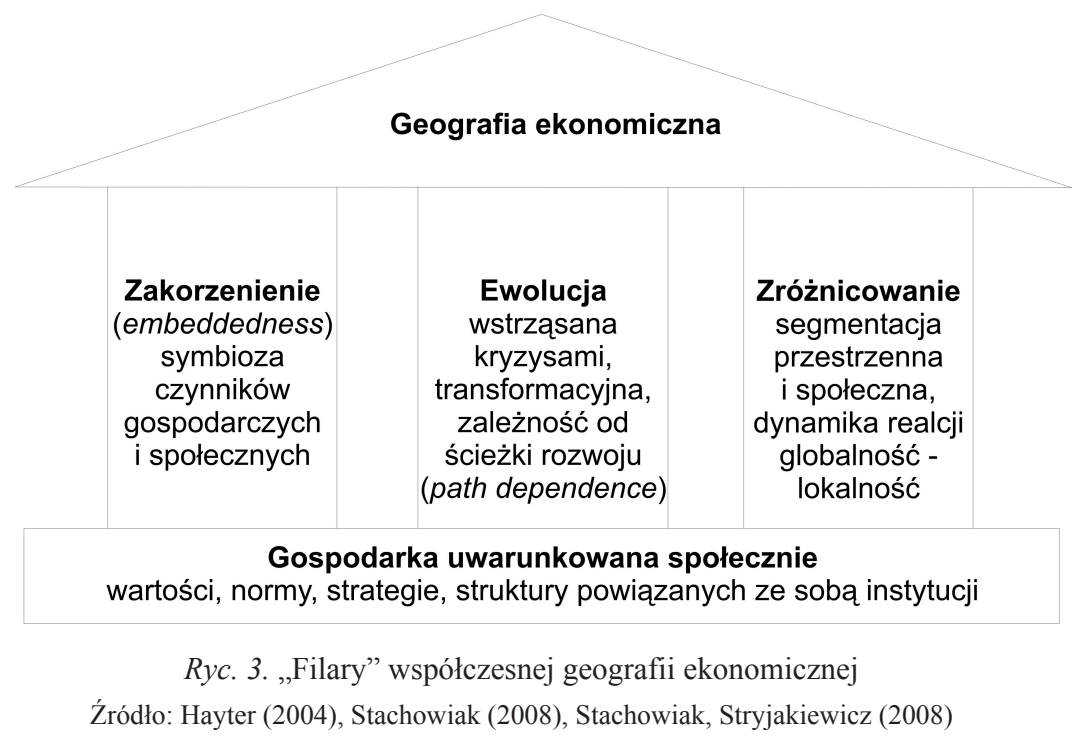

Należy jednak podkreślić, że szczególnie istotne przemiany zachodzą w odniesieniu do zagadnień lokalizacji działalności gospodarczej (zwłaszcza gałęzi i branż nowoczesnych, w tym tzw. sektora kreatywnego). P. Mc Cann i S. Sheppard (2003), a w literaturze polskiej W. Dziemianowicz (2008) wskazują na trzy kierunki, w jakich rozwija się teoria lokalizacji. Pierwszy z nich dotyczy prawidłowości powstawania i rozmieszczenia skupisk działalności gospodarczej (np. klastrów). Drugi kierunek odnosi się do potrzeby redefiniowania przestrzennych kosztów transakcyjnych w kontekście nowych trendów społeczno-ekonomicznych. Trzeci kierunek ewolucji teorii lokalizacji, wymieniony przez cytowanych autorów, to „wprowadzenie do teorii czynnika środowiskowego, rozumianego jako specyficzne warunki lokalne, które wpływają na lokalizację (środowisko przyrodnicze, szeroko rozumiana 

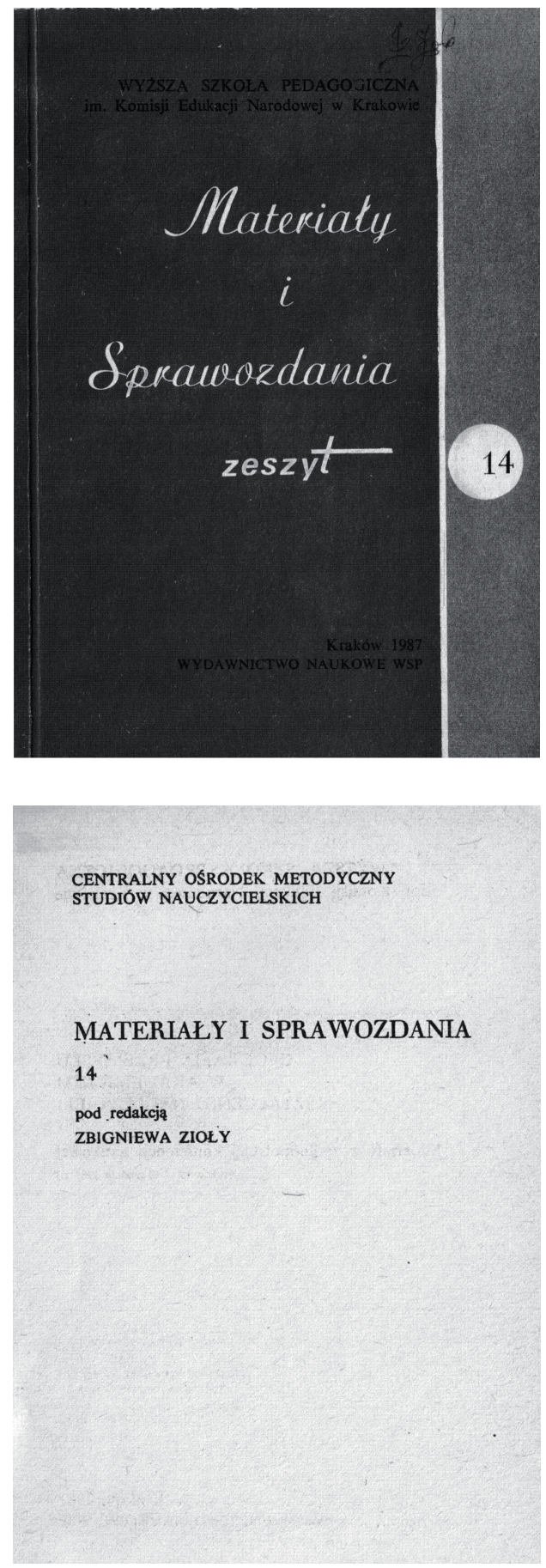

Fot. 1. Okładka, strony tytułowe i spis treści pierwszego tomu serii obecnych Prac Komisji Geografii Przemysłu PTG 
WYŻSZA SZKOLA PEDAGOGICZNA

im. Komisji Edukacji Narodowej w Krakowie

\section{GEOGRAFIA PRZEMYSEU \\ W AKADEMICKIM \\ KSZTALCENIU NAUCZYCIELI}

Materiały z ogólnopolskiej konferencji naukowej (Kraków, 9-10 grudnia 1985 r.)

Kraków 1987 WYDAWNICTWO NAUKOWE WSP

SPIS TRESCI

provadzente.....................

Ludwik Straszerioz: Geografia przenys $3 u$ jako nauka 1 dysoy-

plins nauczanta. . . . . . . . . . . . .

Broniszaw Kortus: Aktualno Klerunkd i probleary badawoze geo-

grafil przerys a . . . . . . . . . . .

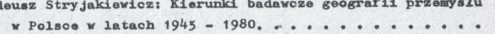
Slavomir P1skorz: Tresc1 z zakresu geografil przemyszu w no-

wyoh programach nauczania azkoly podstakoves 1 brednitej oh Pakuza, Zbignier Ziolos Trései ksztazcenta w zakresio

geograf 11 przemyszu przekazywane ne rykzadach. ..... 58

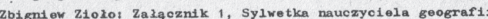

Thion

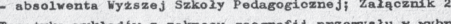

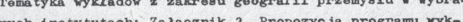
nyoh Ins ty tutach; Zalq̨cznik 3, Propozyoja programu ryk-

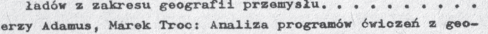

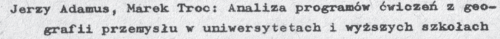
grafil przenysiu $\times$ uniwersytetach i myzszych szkolach 71

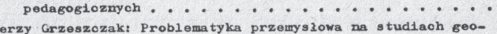

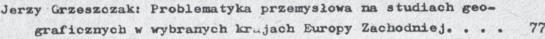
Anna M. Niznik, Zbignier Makieza: Tresol nauczanta geografi1 przemys\}u w programach ksztazconia geografów w Czeoho- ${ }^{4}$ kasko zikandeloff: Konoepoja ́́wiozeń z geografil przemys 3u w Wyzszej szkole Pedagogioznej * Dreźnie . . . . . . 90 
Tadeusz stryjakiewioz

KI ERUNKI BADAYCZE GEOGRAFII PRZEMYSLU Y POLSCE V LATACH 1945 - 1980

Vstepe

Analiza kierunków badavezyoh geograf11 przenys $3 u$ w Polsce stanowl la przedmiot opracowán wielu autorów (m, in, A. Vrzoska 1956, 1964, S. Leszczyokiego, J. Grzeszozaka 1964, J, Grzeszozake 1964 a, A, Kuk11ńskiego 1964 a, z. Prochowskiego 1964, M, Dobrowo1skjoj

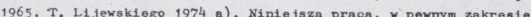

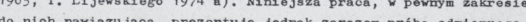
ujecie

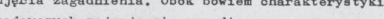

a) krytyozna ocenq dorobku badawozego geograf11 przemyszu z junktu widzenia podstawowyoh sk1adników w1edzy naukowej określa jąeych stopleń rozwoju omawianej dyscypliny;

b) analizą dynamiczn̨ E $e^{26}$ wnyoh trendów exoluoj1 konoepoj1 badawezych geografil przemysiu.

Wydaje się, ze takio ujpoie, majqoe w znaoznym stopniu oharakter syntetyzujący, może stać sį̨ przyozynkiem szerszej dyskus j1 nad stanem polskiej geografil przenisiu.

Przeprovadzona analiza optera sie wyząoznie na kródzach pub1ikowanyoh 1 z tego względu nie obejmuje różnego rodzaju ekspertyz oraz znaoznej ozęsci prac wykonanyoh $\times$ ramach problemów węzıowyoh 1 międzyresortowych, wających niewątpliwie is totne znaczenie dla pelnej oceny dorobku naukowe go geografil przemyszu. Z drugled strony zwraoa uwage fakt, ze problematyka przestrzenna przemyslu jest przedmiotem bedań nie tylko geografów, ale takze przedotavioieli innyoh dyo cyplin naukorych (przede rszystkím ekonomistók), któryoh najkatnitejsze pub11 fe urzeledniono $x$ ninte jszym opracovatu, kykorzystan

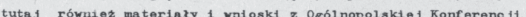

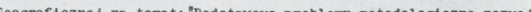
Geogrartozno na temati doda tawowe problany motodologtezne rozwo ju

Nalezy podkreb116, ze prezentowana praca nie stanowi przeglądu pí́mlennictwa z zakresu geograf11 przenryszu, a wymieniene przykładowo publikaoje ma je na oelu jedynie blizszą identyfikacje okreb1onyoh ḱlerunków badawozyoh.

\section{G26une problemy badavoze}

Analizują powojenny dorobek polskied geografil przemysiu wydzielono nastepujące erupy problemów badawozy oh

1. Geneza 1 rozwój obrodków, okręgów, regionów przemyszowych

1. Geneza 1 rozwój oł́rodków, okręgók, regionów przemyszowyoh
gaz̨̨zi 1 branz przemysłu (badania geograficzno-historyczne).

2. Struktura galęziowa 1 przestrzenna oraz regionelizaoja przemys $2 u$.

3. Proeesy uprzemyszowienia 1 zjawiska im towarzyszące (m, in, spoleozne skutki industrializaoj1).

4. Związi przemysiu ze brodowiskiem geografieznym.

5. Czynniki lokalizacji przemys 3u. ysiu.

6. Przestrzenne pouiqzania produkcy jne 1 organizacyjne prze-

Ocena ef ektywnobo1 1okalizacj1 zakładók przemys 1owyoh.

8. Zagadnienia ogolne, teoretyozne 1 metodologiozne.

Probseatyke ga z

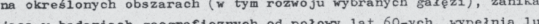

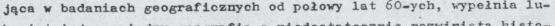
kę istniejqua między geografia a niedostatecznle rozwintęta histo riq gospodarozą. Wyniki tych badań, ktoryoh przykladami sa prace A. Verw1okiego (1957), A. Fajferka (1958), A. Kuk11ńskiego (1959) S. Misztala (1962), J. Ra Jmana (1962), S. M, Zawadzkiego (1963) B. Gruohmana $(1961,1964)$, vzbogaca Jq moz11rośl 1nterpretac J1 wopbzozesny oh struktur przenyszony oh.

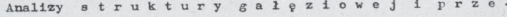
s $t r z e n n e j$ p $r z e m$ y $s$ u oraz 1oh zmian - tradycy jny element badań geografioznyoh - stanowia na jozęsolej przedriot opraoowań typu monografioznego, w tym równleź fragmenty monografil regionalnych, Dominuje w nich podejtole h1storyozno-opisowe. Wb́ród monografi1 ośrodków 1 okcrẹgóm przemrysıowy oh na szezególnq uwage zaszuguja prace L. Straszewioza (1957), L. Fakuly (1965), B. Kortu-

Fot. 2. Początek artykułu T. Stryjakiewicza systematyzującego kierunki badawcze geografii przemysłu w Polsce w latach 1945-1980 
infrastruktura, otoczenie biznesowe). Podkreślenia wymaga fakt, iż oceny tak rozumianego środowiska [...] służą raczej do poznania zachowań ludzi jako mieszkańców, nie zaś przedsiębiorców" (Dziemianowicz 2008, s. 63).

Wydaje się zatem, że we współczesnej teorii lokalizacji mamy do czynienia z ,wymieszaniem” lub „nakładaniem się” kwestii związanych z czynnikami lokalizacji działalności gospodarczej i czynnikami określającymi jakość życia ludności (por. Swianiewicz 2005). Takie podejście jest ściśle powiązane z alternatywnymi (lub raczej komplementarnymi) koncepcjami rozwoju miast i regionów, o których szerzej pisałem we wcześniejszych artykułach (Stryjakiewicz 2008a, 2009a,b), a które poglądowo ilustruje ryc. 4.

\section{Tradycyjne koncepcje}

tworzenie dobrych warunków do przyciagania biznesu (np. niskie podatki, rozwinięta infrastruktura materialna)

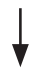

lokalizacja firm

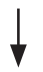

powstawanie nowych miejsc pracy i wysokie tempo wzrostu gospodarczego

migracje ludzi (pracowników ww. firm)

\section{Nowe koncepcje}

tworzenie dobrych warunków do przyciągania kreatywnych i przedsiębiorczych ludzi (np. atrakcyjność miejsc zamieszkania i przestrzeni publicznej, poczucie bezpieczeństwa, atmosfera tolerancji)

migracje kreatywnych i przedsiębiorczych ludzi do atrakcyjnych regionów/miast zakładanie przez ww. ludzi firm w tych atrakcyjnych lokalizacjach

powstawanie nowych miejsc pracy i wysokie tempo wzrostu gospodarczego w wyniku efektu mnożnikowego

Ryc. 4. Lokalizacja działalności gospodarczej w tradycyjnych i nowych koncepcjach rozwoju

Źródło: Stryjakiewicz (2009a)

Na zakończenie tego rozdziału, biorąc pod uwagę okolicznościowy charakter artykułu, należy postawić pytanie: Czy i jakim zakresie zarysowane powyżej przemiany w geografii przemysłu znajdowały odzwierciedlenie w problematyce wydawanych serii oraz cyklu konferencji naukowych organizowanych przez 25 lat na Uniwersytecie Pedagogicznym w Krakowie. Najogólniej można stwierdzić, że konferencje te dobrze spełniły swoją rolę w zakresie odpowiadania na najważniejsze wyzwania, przed którymi stawała i staje geografia przemysłu (lub szerzej: geografia ekonomiczna). Chodzi tu przede wszystkim o analizę miejsca przemysłu w zachodzących współcześnie procesach przestrzennych, takich jak: tercjaryzacja, dezindustrializacja, transformacja, globalizacja i integracja gospodarki. Wśród podejmowanych problemów znalazły się m.in. tak ważne kwestie, jak:

a) korporacje transnarodowe a przestrzenna organizacja gospodarki,

b) rola nowych technologii informacyjno-komunikacyjnych $\mathrm{w}$ transformacji przestrzennych struktur gospodarczych,

c) dialektyka globalność - lokalność; przedsiębiorstwo a region. 
Szczególną uwagę poświęcono transformacji przemysłu w Polsce w kontekście europejskim i globalnym. W ujęciu „branżowym” za symboliczne można uznać przejście od analizy problemów przemysłu rolno-spożywczego (temat 6 . konferencji) do oceny funkcji przemysłu i usług w kształtowaniu społeczeństwa informacyjnego (temat 24. konferencji). Łączenie problematyki przemysłowej i usługowej stało się już trwałą cechą krakowskiej konferencji, podobnie jak jej umiędzynarodowienie.

\section{OCENA AKTUALNEGo STANU POLSKIEJ GEOGRAFII PRZEMYSŁU}

Aktualny stan polskiej geografii przemysłu jest konsekwencją zarówno zarysowanej powyżej ewolucji samej dyscypliny naukowej, jak i przemian instytucjonalnych. W raporcie wykonanym dla Komitetu Nauk Geograficznych PAN (Stryjakiewicz 2008b), którego niektóre wyniki zostaną tu przytoczone, stwierdziłem, że relatywne znaczenie geografii przemysłu w ogólnym dorobku nauk geograficznych w Polsce podlegało dużym wahaniom. Było to związane m.in. ze zmieniającą się rolą przemysłu w gospodarce, różną dostępnością materiałów źródłowych w różnych okresach, a także z rolą uczonych zainteresowanych tą dziedziną badań. Na podkreślenie zasługuje fakt, że dzięki nieprzerwanej działalności Komisji Geografii Przemysłu PTG ukazywały się okresowe oceny dorobku tej dyscypliny (m.in. pod redakcją S. Misztala i Z. Zioło w 1998 r.). W 2001 r., również z inicjatywy Komisji, wydana została monografia Polska geografia przemystu i budownictwa $w$ XX wieku (pod redakcją T. Marszała), ukazująca jej dorobek przez pryzmat sylwetek pracowników naukowych zajmujących się badaniami w omawianej dziedzinie.

Pod względem ilościowym w polskiej geografii przemysłu na przełomie XX i XXI wieku najliczniejszą grupę stanowią prace dotyczące przemian strukturalnych przemysłu w warunkach transformacji (włączając w to procesy restrukturyzacji). Problemom tym poświęcono kilka prac habilitacyjnych (Paszkowski 1996, Stryjakiewicz 1999, Tkocz 2001), wiele prac doktorskich, a także szereg konferencji naukowych, których rezultaty opublikowane są m.in. w serii Prac Komisji Geografii Przemysłu PTG. Wyniki tych badań przyczyniły się do lepszego rozpoznania uwarunkowań i przebiegu procesu transformacji w różnych kontekstach i różnych skalach przestrzennych. W przyszłości należałoby położyć większy nacisk na międzynarodowe studia porównawcze - w celu pełniejszej identyfikacji mechanizmów tego procesu i sformułowania prawidłowości nim rządzących.

Konsekwencją transformacji przemysłu są zmiany form jego oddziaływania na rozwój regionalny i lokalny. To zagadnienie stanowi kolejny intensywnie rozwijający się w ostatnich latach kierunek badań geografii przemysłu w Polsce, i to zarówno w odniesieniu do poszczególnych branż (np. przemysłu zaawansowanej technologii - Gurbała 2004), przedsiębiorstw (w szczególności korporacji ponadnarodowych - Domański 2001, Stryjakiewicz, red. 2004, Domański i in. 2008), jak i obszarów o specyficznych uwarunkowaniach lokalizacyjnych (np. specjalnych stref ekonomicznych - Domański, Gwosdz, red. 2005). Wśród innych prac na uwagę zasługują: podręcznik akademicki geografii przemysłu Wielońskiego (2000) oraz atlas Przedsiębiorstwa w przestrzeni Warszawy (Śleszyński 2006).

Dorobek polskiej geografii przemysłu na forum światowym prezentowany jest głównie na konferencjach organizowanych przez Międzynarodową Unię Geograficzną i jej Komisję Dynamiki Przestrzeni Ekonomicznej (np. w 2006 r. na konferencjach w Auckland 
i Brisbane). Jest to jednak wciąż udział zbyt mały w stosunku do zainteresowania tą problematyką (symptomatyczny jest fakt, że na konferencji w Auckland geografowie z zagranicy prezentowali więcej referatów dotyczących przemysłu w Polsce niż geografowie z Polski). Zbyt mała jest również aktywność polskich geografów przemysłu w międzynarodowych projektach badawczych, np. w 6. i 7. Programie Ramowym Unii Europejskiej. Uczestniczą w nich m.in. geografowie z Uniwersytetu Jagiellońskiego (projekt Moving frontier: The changing geography of production in labour intensive industries) oraz Uniwersytetu im. Adama Mickiewicza w Poznaniu (projekt $A C R E$, dotyczący tzw. creative industries w regionach metropolitalnych Europy).

Tab. 1. Ocena stanu polskiej geografii przemysłu

\begin{tabular}{|c|c|}
\hline Mocne strony & Słabe strony \\
\hline $\begin{array}{l}\text { - Istnienie struktur organizacyjnych umoż- } \\
\text { liwiających kontakty między geografami } \\
\text { przemysłu z całego kraju, wymianę do- } \\
\text { świadczeń i prezentację dorobku (działal- } \\
\text { ność Komisji Geografii Przemysłu PTG, } \\
\text { tradycja corocznych konferencji organizo- } \\
\text { wanych przez Uniwersytet Pedagogiczny } \\
\text { w Krakowie, wydawanie serii Prace } \\
\text { Komisji Geografii Przemysłu PTG) } \\
\text { - Po okresie spadku zainteresowania } \\
\text { - duża liczba młodych badaczy podejmu- } \\
\text { jących problematykę geografii przemysłu } \\
\text { - Aktualność i różnorodność podejmowanej } \\
\text { problematyki badawczej, coraz silniejszy } \\
\text { związek z potrzebami praktyki }\end{array}$ & $\begin{array}{l}\text { - „Luka pokoleniowa” wśród samodzielnych } \\
\text { pracowników naukowych zajmujących się } \\
\text { problematyką geografii przemysłu } \\
\text { - Zbyt mały potencjał kadrowy i organizacyjny } \\
\text { w stosunku do rosnącego popytu na wyniki } \\
\text { badań z dziedziny szeroko pojętej geografii } \\
\text { przemysłu, potęgowany „odchodzeniem” czę- } \\
\text { ści geografów od problematyki przemysłowej } \\
\text { - Zbyt powolna adaptacja dorobku światowego, } \\
\text { zwłaszcza w płaszczyźnie teoretycznej } \\
\text { - Duża liczba prac o charakterze przyczyn- } \\
\text { karskim i opisowym, o lokalnym znaczeniu; } \\
\text { słabość generalizacji i międzynarodowych } \\
\text { studiów porównawczych } \\
\text { - Niedostateczny marketing kompetencji i osiag- } \\
\text { nięć badawczych geografii przemysłu, zwłasz- } \\
\text { cza wśród innych dyscyplin naukowych } \\
\text { - Niski, często bardzo tradycyjny poziom na- } \\
\text { uczania problematyki geografii przemysłu } \\
\text { w szkołach; przestarzałe treści nauczania, } \\
\text { a nawet błędy w podręcznikach szkolnych }\end{array}$ \\
\hline
\end{tabular}

Źrodło: Stryjakiewicz (2008b, s. 153), ze zmianami autora

W tabeli 1 dokonano próby syntetycznej oceny stanu polskiej geografii przemysłu poprzez prezentację jej mocnych i słabych stron. Stopniowe usuwanie wymienionych w tabeli słabości - to najważniejsze wyzwanie stojące przed geografią przemysłu w Polsce. Największa wątpliwość dotycząca przyszłego rozwoju związana jest z miejscem tej dyscypliny w systemie nauk geograficznych. W szczególności należałoby podjąć dyskusję nad następującymi pytaniami: 
1) Dlaczego szybkiemu wzrostowi popytu na badania przestrzenno-ekonomiczne nie towarzyszy proporcjonalny wzrost potencjału kadrowo-organizacyjnego odpowiednich jednostek geograficznych zajmujących się tą problematyką?

2) Dlaczego kolejne pola badawcze „oddawane” są ekonomistom?

3) Dlaczego w systemie edukacyjnym nauczanie geografii (w tym geografii przemysłu) łączone jest wyłącznie z nauczaniem bloku „przyroda” (a nie np. „przedsiębiorczość”, którą tak skutecznie propaguje Zakład Przedsiębiorczości Instytutu Geografii Uniwersytetu Pedagogicznego im. KEN w Krakowie)?

To ostatnie wzmocniłoby pozycję nie tylko geografii przemysłu (i geografii ekonomicznej), ale całej geografii, i stworzyłoby nowe możliwości zawodowe dla absolwentów (co wydaje się szczególnie istotne w okresie zaznaczającego się niżu demograficznego w szkołach). Wydaje się, że - jak dotąd - brak jest w środowisku geografów „masy krytycznej”, która by taki zwrot zapoczątkowała. Stąd zarysowana powyżej sytuacja polskiej geografii przemysłu zapewne nie ulegnie w najbliższych latach poważniejszym zmianom. Można jedynie z dużym prawdopodobieństwem zakładać, że proces ewolucji gospodarki wymusi zmniejszenie ,autonomii” geografii przemysłu i pełniejszą integrację różnych subdyscyplin geografii ekonomicznej.

\section{ZAKOŃCZENIE}

Przedstawiona w artykule analiza dowodzi, że problemów i wyzwań stojących przed geografią przemysłu jest sporo i że z pewnością „będziemy mieli co robić” przez następne 25 lat. W tekście często pojawiały się słowa: „zmienność”, ,zmiany”, ,przemiany”. I to dobrze: na ogół łączą się one z postępem. Ale jednocześnie chciałoby się, aby w tej zmienności były jakieś układy odniesienia, coś, co nazwałbym „filarami, które podtrzymują tę całą konstrukcję zmienności”. Ich wartość ocenia czas. Tymi filarami są zarówno ludzie, a wśród nich Dostojny Jubilat - Prof. dr hab. Stanisław Misztal (fot. 3), jak i wydarzenia, takie jak krakowskie spotkania na Uniwersytecie Pedagogicznym, które od 25 lat ułatwiają wymianę myśli w dziedzinie naszych zainteresowań, tj. geografii przemysłu i dyscyplin pokrewnych. Niech zatem końcowy fragment tego okolicznościowego artykułu będzie wyrazem podziękowań dla jej twórców i organizatorów za 25 lat ogromnego wysiłku organizacyjnego, za to, że są tak konsekwentni w swych działaniach i od 25 lat otwierają nam gościnne mury swej uczelni. Gratulując tego Jubileuszu, życzymy dalszego dynamicznego rozwoju przez kolejne 25 lat. Ad multos annos! 


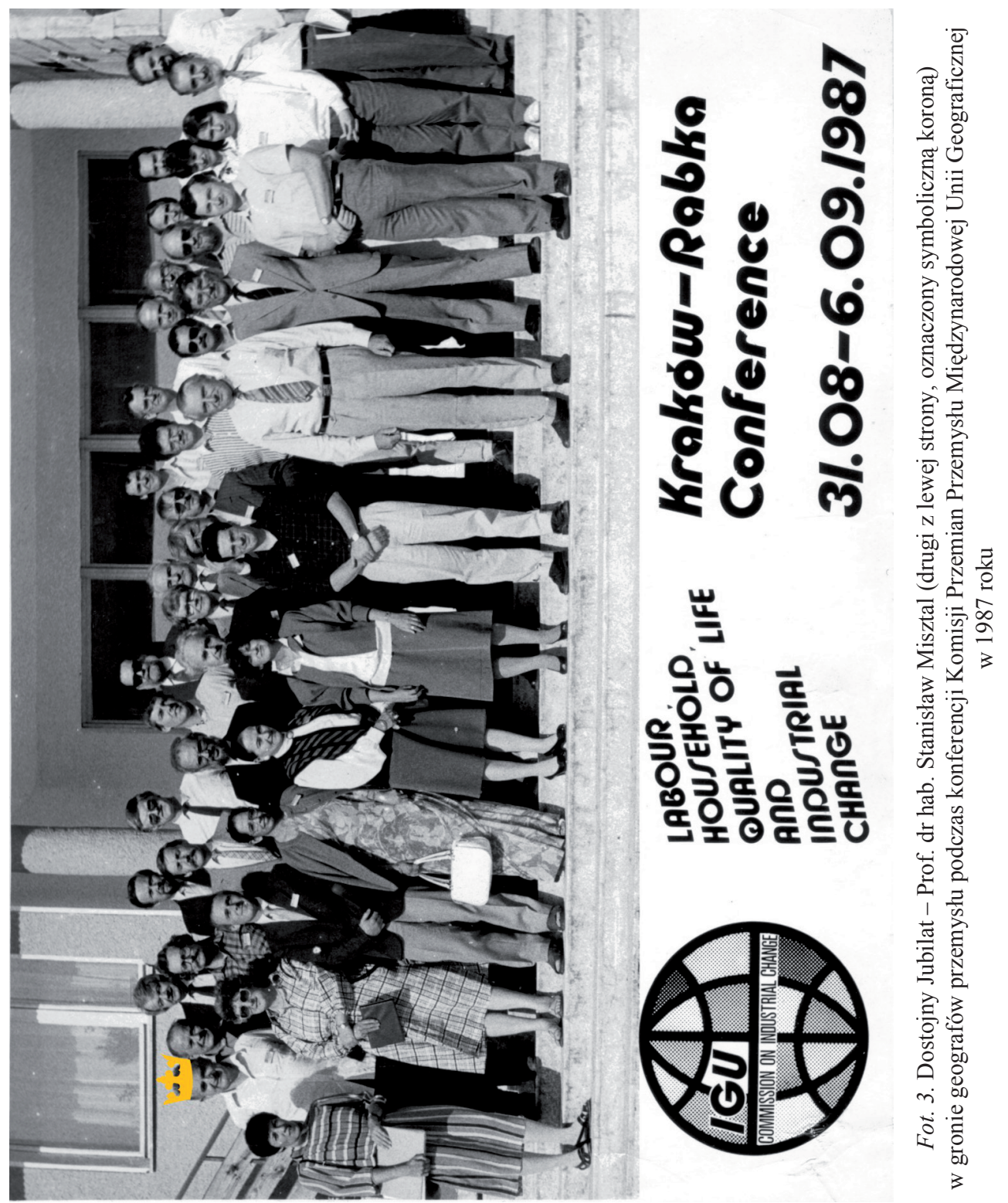




\section{Literatura}

Domański B., 2001, Kapitał zagraniczny w przemyśle Polski, Instytut Geografii i Gospodarki Przestrzennej, Uniwersytet Jagielloński, Kraków

Domański B., 2004, Nowe idee w światowej geografii społeczno-ekonomicznej, [w:] Z. Chojnicki (red.), Geografia wobec problemów teraźniejszości i przyszłości, Bogucki Wydawnictwo Naukowe, Poznań

Domański B., Gwosdz K. (red.), 2005, Dziesięć lat doświadczeń polskiej specjalnej strefy ekonomicznej. Mielec 1995-2005, Instytut Geografii i Gospodarki Przestrzennej Uniwersytet Jagielloński, Kraków i ARP o/Mielec

Domański B., Działek J., Górecki J., Gwosdz K., Janas K., Jarczewski W., Kocaj A., Micek G., Padło T., 2008, Inwestycje zagraniczne w Malopolsce 1989-2007. Opracowanie przygotowane na zlecenie Urzędu Marszałkowskiego Województwa Małopolskiego, Kraków

Dziemianowicz W., 1997, Kapital zagraniczny a rozwój regionalny i lokalny w Polsce, „Studia Regionalne i Lokalne", z. 20 (53), UW. EIRRiL, Warszawa

Dziemianowicz W., 2008, Konkurencyjność gmin w kontekście relacji władze lokalne - inwestorzy zagraniczni, Wydawnictwa Uniwersytetu Warszawskiego, Warszawa

Gurbała M., 2004, Rola przemystu zaawansowanej technologii w rozwoju regionalnym i lokalnym, Wyd. Instytutu Technologii Eksploatacji, Radom

Gwosdz K., 2004, Koncepcja zależności od ścieżki (path dependence) w geografii społeczno-ekonomicznej, Przegląd Geograficzny, t. 76, z. 4, s. 433-456

Hayter R., 2004, Economic Geography as Dissenting Institutionalism: the Embeddedness, Evolution and Differentation of Regions, Geografiska Annaler, Series B: Human Geography, t. 86, z. 2, s. $95-115$

Kortus B., 1987, Aktualne kierunki i problemy badawcze geografii przemyshu, [w:] Z. Zioło (red.), Geografia przemystu w akademickim ksztatceniu nauczycieli, Materiały i sprawozdania, z. 14, Wydawnictwo Naukowe WSP w Krakowie, Kraków

Marszał T. (red.), 2001, Polska geografia przemystu i budownictwa w XX wieku, Wyd. Uniwersytetu Łódzkiego, Łódź

McCann P., Sheppard S., 2003, The rise, fall and rise again of industrial location theory, Regional Studies, vol. 37/6-7

Misztal S., Zioło Z. (red.), 1998, Dorobek polskiej geografii przemystu w badaniach ośrodków akademickich, Wyd. PAN Kraków, Warszawa-Kraków

Paszkowski M., 1996, Zmiany strukturalne przemystu. Metody badania i tendencje światowe a transformacje w krajach Europy Środkowo-Wschodniej, Wyd. Uniwersytetu Jagiellońskiego, Kraków

Stachowiak K., 2008, Podejście instytucjonalne w geografii ekonomicznej i badaniach regionalnych, [w:] T. Czyż, T. Stryjakiewicz (red.), O nowy ksztalt badań regionalnych w geografii i gospodarce przestrzennej, Biuletyn KPZK PAN, z. 237, Warszawa, s. 104-128

Stachowiak K., Stryjakiewicz T., 2008, Institutional approach in economic geography and its relevance to regional studies, [w:] T. Stryjakiewicz, P. Jurczek (red.), Changing concepts, trends, and experiences in regional development and regional policy, Quaestiones Geographicae, z. 27 B/1, Wydawnictwo Naukowe Uniwersytetu im. Adama Mickiewicza w Poznaniu, Poznań

Stryjakiewicz T., 1987, Kierunki badawcze geografii przemystu w Polsce w latach 1945-1980, [w:] Z. Zioło (red.), Geografia przemystu w akademickim kształceniu nauczycieli. Materiały i sprawozdania, z. 14, Wydawnictwo Naukowe WSP w Krakowie, Kraków

Stryjakiewicz T., 1999, Adaptacja przestrzenna przemystu $w$ Polsce $w$ warunkach transformacji, Wydawnictwo Naukowe UAM, Poznań

Stryjakiewicz T., 2001, Koncepcja usieciowienia (networking) w badaniach przestrzenno-ekonomicznych, [w:] Rogacki H. (red.), Koncepcje teoretyczne i metody badań geografii społeczno-ekonomicznej i gospodarki przestrzennej, Bogucki Wydawnictwo Naukowe, Poznań, s. 37-47 
Stryjakiewicz T., 2005, Sieciowa organizacja gospodarki a rozwój regionalny, [w:] T. Czyż, H. Rogacki (red.), Wspótczesne problemy i koncepcje teoretyczne badań przestrzenno-ekonomicznych, Biuletyn KPZK PAN, z. 219, Warszawa, s. 38-56

Stryjakiewicz T., 2007, Orientacja instytucjonalna $w$ geografii ekonomicznej i jej znaczenie $w$ analizie procesów transformacji struktur przestrzennych, [w:] J. Lach, M. Borowiec, T. Rachwał (red.), Procesy transformacji spoteczno-ekonomicznych i przyrodniczych struktur przestrzennych, Wydawnictwo Naukowe AP w Krakowie, Kraków, s. 107-118

Stryjakiewicz T., 2008a, Rozwój sektora kreatywnego w regionach metropolitalnych, [w:] T. Stryjakiewicz, J.J. Parysek (red.), Region społeczno-ekonomiczny i rozwój regionalny, Bogucki Wydawnictwo Naukowe, Poznań, s. 105-119

Stryjakiewicz T., 2008b, Stan i perspektywy rozwoju geografii ekonomicznej w Polsce. Geografia przemystu, [w:] S. Liszewski, J. Łoboda, W. Maik (red.), Stan i perspektywy rozwoju geografii w Polsce. Raport z prac Komitetu Nauk Geograficznych Polskiej Akademii Nauk w kadencji 2003-2006, Wydawnictwo Uczelniane Wyższej Szkoły Gospodarki w Bydgoszczy, Bydgoszcz, s. $150-155$

Stryjakiewicz T., 2009a, Nowe spojrzenie na czynniki lokalizacji działalności gospodarczej, [w:] I. Jażewicz (red.), Wspótczesne problemy przemian strukturalnych przestrzeni geograficznej. Wydawnictwo Naukowe Akademii Pomorskiej, Słupsk, s. 94-102

Stryjakiewicz T., 2009b, Lokalizacja firm i zachowania przestrzenne pracowników sektora informatycznego (na przyktadzie poznańskiego obszaru metropolitalnego), [w:] Z. Zioło, T. Rachwał (red.), Funkcje przemystu $w$ ksztaltowaniu społeczeństwa informacyjnego, Prace Komisji Geografii Przemysłu PTG, z. 13, Wydawnictwo Naukowe UP w Krakowie, Kraków, s. 21-33

Stryjakiewicz T. (red.), 2004, Wplyw inwestorów zagranicznych na rozwój regionalny i lokalny na przykładzie GlaxoSmithKline Pharmaceuticals S.A. w Poznaniu, Bogucki Wydawnictwo Naukowe, Poznań

Swianiewicz P., 2005. Nowe interpretacje teoretyczne polityki miejskiej, Studia Regionalne i Lokalne, z. 4

Śleszyński P., 2006, Przedsiębiorstwa w przestrzeni Warszawy, Atlas Warszawy, 9, Instytut Geografii i Przestrzennego Zagospodarowania PAN, Warszawa

Tkocz M., 2001, Restrukturyzacja przemyslu regionu tradycyjnego, Wyd. Uniwersytetu Śląskiego, Katowice

Wieloński A., 2000, Geografia przemystu, Wyd. Naukowe PWN, Warszawa

Zioło Z., 1987, Wprowadzenie, [w:] Z. Zioło (red.), Geografia przemystu w akademickim ksztatceniu nauczycieli, Materiały i sprawozdania, z. 14, Wydawnictwo Naukowe WSP w Krakowie, Kraków

\section{Changes in industrial geography}

The article has a 'celebratory' character connected with two jubilees:

- the 25th anniversary of the Conference on Industrial Geography, organised by the Institute of Geography, Cracow Pedagogical University, in collaboration with the Industrial Geography Committee of the Polish Geographical Society; and

- the 80th birthday of Professor Stanisław Misztal, Honorary President of the Industrial Geography Committee of the Polish Geographical Society.

This is a good opportunity to analyse and discuss the changes which have taken place in industrial geography over this period. The discussion, presented in the first section, embraces the following issues:

1. Change in the definition of the substantive scope of industrial geography;

2. Methodological trends and research directions; 
3. A new look at the location of economic activity;

4. The place of industry in on-going spatial processes.

The next section of the article addresses the question of how the changes are reflected in the 25-years' history of the Cracow Conference. The last section presents evaluation of the current state of the Polish industrial geography, including its strengths and weaknesses.

Prof. dr hab. Tadeusz Stryjakiewicz

Uniwersytet im. Adama Mickiewicza w Poznaniu

Instytut Geografii Społeczno-Ekonomicznej i Gospodarki Przestrzennej

Zakład Polityki Regionalnej i Integracji Europejskiej

e-mail: tadek@amu.edu.pl

www.zprie.amu.edu.pl 